\title{
Prevalence and Psychological Intervention of Internet and Smart Phone Addiction
}

\author{
G. Archana, P. Balaji
}

\begin{abstract}
This empirical research was aimed to explore the prevalence and psychological interventions of college youth towards internet and smart phone addiction in Chennai city of Tamil Nadu. This study was adopted exploratory research design to explore the perception of college youth towards their addiction of internet and smart phone in their day-to-day lives. This study was adopted survey method and structured questionnaire of 173 were collected from college students. The result indicates that college youth have higher addiction towards internet and cognitive confinement factor, laxness factor and usage supremacy factor are the major factors of internet usage among college students. The college youth are suggested to reduce the usage of internet and smartphone by giving focus to other physical activities. The college youth are suggested to have self-control and determination to use smart phone whenever there is actual need for appropriate usage.
\end{abstract}

Keywords:Internet, Smart Phone, Addiction, Cognitive Confinement, Laxness and Usage Supremacy.

\section{INTRODUCTION}

The internet and smart phone addiction lead to pathological usage among many people due to growth of communication and information technology growth in India. The hours spent on smart phone and usage of internet is drastically increasing day-by-day especially, among the youngsters. There are many individuals who use the smart phone and internet even by reducing their sleeping and working hours every day. The prevalence and psychological interventions of smart phone addiction and internet addiction were increased due to the growth of these sectors. The smart phone market in India was the one of the highest contributors as compared to other countries at the global level. The higher usage of smart phone leads to health issues and increases the risk factors especially among adolescents in India.

\section{SMART PHONE AND INTERNET ADDICTION}

\section{A. UCLA Loneliness Scale}

Russell, D, Peplau, L. A..\& Ferguson, M. L. (1978) have developed a scale to measure the loneliness for self-reported examination of UCLA (University of Clifornia, Los Angeles) Loneliness scale for the purpose of understanding the relationship between the psychological experience and loneliness perception. Russell. D (1996) developed UCLA $3^{\text {rd }}$ Version to validate and consistency and reliability of same to explore the loneliness perception of individuals.

\section{B. Smartphone Addiction Scale (SAS)}

Min Kwon et al., (2013) assessed the smart phone

Revised Manuscript Received on December 20, 2019.

* Correspondence Author

G. Archana, Ph.D. Research Scholar, Department of Commerce, VISTAS, Chennai, Tamil Nadu, India. Email:archgovi3096@gmail.com

Dr. P. Balaji*, Assistant Professor, P.G and Research Department of Commerce, Guru Nanak College (Autonomous), Chennai, Tamil Nadu, India. Email: aravindbalaji23@gmail.com addiction of adolescents with the use of receiver operating characteristics curve. The scale was validated for its consistency and reliability for the exploration and future usage.

\section{Smartphone Addiction Proneness Scale (SAPS)}

Kim et al., (2014) developed a scale with twenty-nine items to existence and addiction of internet and smart phone usage of individuals. There are four important dimensions were explored by the authors namely, disturbance of adoptive functions, virtual life orientation, withdrawal and tolerance. The authors predicted that smart phone usage was greatly provides spotlight to internet usage among its users. Dmitri Rozgonjux et al., (2016) developed the smaller version of SAPS Scale. Further, validated the scale coined the name as Estoninan Smartphone Addiction Scale (E-SAPS18).

\section{The Korean Internet Addiction Scale (KS-Scale)}

Min Kwon et.al.,(2013) conducted a diagnostic study to explore the perception of Korean adolescents on internet addiction in their day-to-day life. This scale was primarily focusing on depression and suicidal ideation via internet addiction was explored and they proved that gender is not a parameter to differentiate the prevalence of internet addiction.

\section{REVIEW OF LITERATURE}

Alosaimiet al., (2016) stated that university students are spending more than eight hours in internet and social media and they use minimum four different applications per day in Saudi Arabia.

Hauget al., (2015) conducted survey among Swiss vocation schools to measure and understand the smart phone usage of students. The result indicates that younger adolescents have higher addiction towards smart phone as compared to young adults.

Sharma et al., (2014) carried an exploratory study to examine the level of addiction and prevalence of internet and smart phone usage of Madhya Pradesh students. The result proves that professional course students have higher internet and smart phone addiction as compared to other course students and the author suggested to have therapeutic interventions which plays vital role in reduction of internet and smart phone usage among students.

Young, K. S. (2007) found that middle aged people those who have 4-year degree are exposed to higher internet addiction as compared to other age groups.

Kibona, L., \&Mgaya, G. (2015) found the effects of smart phone usage on the academic performance of university students and result proves that higher the smart phone usage lesser the academic performance and vice-versa.

Nayak, J. K. (2018) examined the correlation among usage, addiction of smartphone and academic 
performance of students in higher learning institutions in India. The researcher found that gender plays the moderating role for the influence on academic performance of university students.

\section{STATEMENT OF THE PROBLEM}

The internet and smart phone are become order of the day among all the college students due to technological growth and accessibility to internet. India is the third largest internet users base across the globe and expected to reach second place end of the year 2020. This results in various physochological and physical problems to youngsters those who use the internet and smart phone excessively. There is a need to address the prevalence and psychological interventions that contributes for the addiction of internet and smart phone among the youngsters to overcome the problems faced by today's generation users.

\section{RESEARCH OBJECTIVES}

1. To understand the socio-economic background of the college students in Chennai city of Tamil Nadu.

2. To explore the dimensions of Internet and Smartphone addition various of College students

\section{RESEARCH METHODOLOGY AND QUESTIONNAIRE DESIGN}

This research was adopted exploratory and empirical research design to conduct survey from 173 college students of Chennai city of Tamil Nadu with the help of structured questionnaire developed on internet and smart phone addiction. The convenience sampling technique was adopted to gather the primary information and perception of internet and smart phone users in the study area. The structured questionnaire were designed with two sections namely, demographic profiles and internet and social media addiction variables measured in the appropriate nominal and five point Likert scales respectively.

\section{DATA ANALYSIS}

The data collected were subjected to analysis of data with the help of PSPP version 1.0.1 and the statistical tools such as, percentage analysis, descriptive analysis and exploratory factor analysis has been applied to draw meaningful solutions to the research problem.

\section{RESULT AND DISCUSSION}

\section{A. Demographic profiles of the respondents:}

The demographic profiles of the respondent are majority of the respondents are male $(65.9 \%)$, hailing from nuclear family and have monthly family income of between Rs.20, 000 to 40, 000. All the respondents are single (100.0\%) and possess smart phone with internet accessibility (100.0\%). Majority of the respondents are agreed that they may feel very difficult survive without Smartphone and Internet $(55.4 \%)$. Majority of the respondents are agreed that they use data card $(79.2 \%)$ for the internet usage followed by, Wifi $(13.9 \%)$ and other sources $(6.9 \%)$.

\section{B. Dimensions of Internet and Smart Phone Addiction Variables:}

The exploratory factor analysis has been applied for fifteen internet and smart phone addiction variables with Varimax rotation and Principle Component Method (PCA) of factorization. The results are tabulated and presented in Table 1 and Table 2.

Table 1: Descriptive Statistics

\begin{tabular}{|c|c|c|}
\hline $\begin{array}{c}\text { Internet and Smart Phone Addiction } \\
\text { Variables }\end{array}$ & Mean & $\begin{array}{c}\text { Std. } \\
\text { Deviation }\end{array}$ \\
\hline I am obsessed due to my phone & 2.97 & 1.243 \\
\hline $\begin{array}{l}\text { I feel stressed when I am not using } \\
\text { my phone }\end{array}$ & 2.55 & 1.309 \\
\hline $\begin{array}{l}\text { I tried hard to control my addiction } \\
\text { towards phone }\end{array}$ & 3.14 & 1.279 \\
\hline $\begin{array}{l}\text { I am using my phone longer than } \\
\text { intended }\end{array}$ & 3.34 & 1.202 \\
\hline $\begin{array}{l}\text { I often regretted for using phone for } \\
\text { long hours }\end{array}$ & 3.2 & 1.358 \\
\hline $\begin{array}{l}\text { I feel comfortable in the virtual world } \\
\text { rather than real world }\end{array}$ & 2.32 & 1.389 \\
\hline $\begin{array}{l}\text { I feel impatient when I don't get any } \\
\text { notification in phone }\end{array}$ & 2.46 & 1.358 \\
\hline $\begin{array}{l}\text { I feel scary when my phone running } \\
\text { out of battery }\end{array}$ & 2.83 & 1.399 \\
\hline $\begin{array}{l}\text { I often search for Wi-Fi signal around } \\
\text { me }\end{array}$ & 2.45 & 1.428 \\
\hline $\begin{array}{l}\text { I Feel identify crisis without my } \\
\text { mobile phone }\end{array}$ & 2.43 & 1.206 \\
\hline $\begin{array}{l}\text { I neglect important activities due to } \\
\text { overuse of mobile phone }\end{array}$ & 2.84 & 1.395 \\
\hline $\begin{array}{l}\text { I missed a meal due to high } \\
\text { engagement towards mobile phone }\end{array}$ & 2.18 & 1.389 \\
\hline $\begin{array}{l}\text { I have experienced sleep deprivation } \\
\text { due to my mobile phone }\end{array}$ & 2.79 & 1.464 \\
\hline $\begin{array}{l}\text { I use various mobile applications to } \\
\text { just pass time }\end{array}$ & 3.08 & 1.374 \\
\hline $\begin{array}{l}\text { I frequently send online requests to } \\
\text { people to engage in game or } \\
\text { friendship }\end{array}$ & 2.23 & 1.377 \\
\hline $\begin{array}{l}\text { I feel nervous when I am not get any } \\
\text { like or comments for my posts in } \\
\text { Phone }\end{array}$ & 2.08 & 1.250 \\
\hline $\begin{array}{l}\text { I feel restless when I not use my } \\
\text { mobile phone }\end{array}$ & 2.38 & 1.278 \\
\hline $\begin{array}{l}\text { I ignore the people around me to use } \\
\text { my mobile phone }\end{array}$ & 2.43 & 1.352 \\
\hline
\end{tabular}

Table 1 indicates that mean values for fifteen internet and smart phone addiction are robust in nature due to smaller standard deviation values. The lower standard deviation values prove that the data is normally distributed to all the respondents. 
Table 2: Factorisation of Internet and Smart Phone Addiction Variables

\begin{tabular}{|c|c|c|c|c|}
\hline $\begin{array}{l}\text { Factor } \\
\text { Names }\end{array}$ & $\begin{array}{c}\text { Internet and Smart } \\
\text { Phone Addiction } \\
\text { Variables }\end{array}$ & $\begin{array}{l}\text { Factor } \\
\text { Loadings }\end{array}$ & $\begin{array}{c}\% \text { of } \\
\text { Variance } \\
\text { Explained }\end{array}$ & $\begin{array}{l}\text { Reliability } \\
\text { Value }\end{array}$ \\
\hline \multirow{8}{*}{ 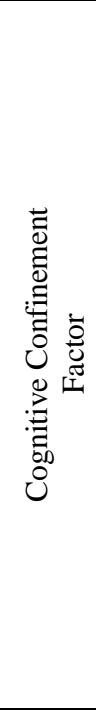 } & $\begin{array}{l}\text { I feel restless when I not } \\
\text { use my mobile phone }\end{array}$ & 0.750 & \multirow{8}{*}{ 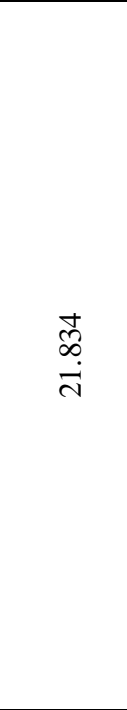 } & \multirow{8}{*}{$\underset{\infty}{\infty}$} \\
\hline & $\begin{array}{l}\text { I feel nervous when I am } \\
\text { not getting any like or } \\
\text { comments for my posts } \\
\text { in Phone }\end{array}$ & 0.682 & & \\
\hline & $\begin{array}{l}\text { I frequently send online } \\
\text { requests to people to } \\
\text { engage in game or } \\
\text { friendship }\end{array}$ & 0.652 & & \\
\hline & $\begin{array}{l}\text { I feel impatient when I } \\
\text { don't get any notification } \\
\text { in phone }\end{array}$ & 0.634 & & \\
\hline & $\begin{array}{l}\text { I feel stressed when I am } \\
\text { not using my phone }\end{array}$ & 0.630 & & \\
\hline & $\begin{array}{l}\text { I feel comfortable in the } \\
\text { virtual world rather than } \\
\text { real world }\end{array}$ & 0.611 & & \\
\hline & $\begin{array}{l}\text { I Feel identify crisis } \\
\text { without my mobile } \\
\text { phone }\end{array}$ & 0.584 & & \\
\hline & $\begin{array}{l}\text { I feel scary when my } \\
\text { phone running out of } \\
\text { battery }\end{array}$ & 0.501 & & \\
\hline \multirow{6}{*}{ 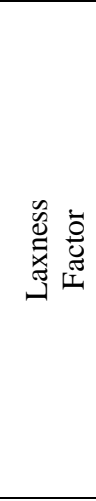 } & $\begin{array}{l}\text { I have experienced sleep } \\
\text { deprivation due to my } \\
\text { mobile phone }\end{array}$ & 0.717 & \multirow{6}{*}{ 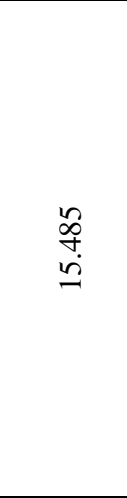 } & \multirow{6}{*}{$\frac{2}{\infty}$} \\
\hline & $\begin{array}{l}\text { I ignore the people } \\
\text { around me to use my } \\
\text { mobile phone }\end{array}$ & 0.595 & & \\
\hline & $\begin{array}{l}\text { I often search for Wi-Fi } \\
\text { signal around me }\end{array}$ & 0.579 & & \\
\hline & $\begin{array}{l}\text { I missed a meal due to } \\
\text { high engagement } \\
\text { towards mobile phone }\end{array}$ & 0.571 & & \\
\hline & $\begin{array}{l}\text { I use various mobile } \\
\text { applications to just pass } \\
\text { time }\end{array}$ & 0.569 & & \\
\hline & $\begin{array}{l}\text { I neglect important } \\
\text { activities due to overuse } \\
\text { of mobile phone }\end{array}$ & 0.454 & & \\
\hline \multirow{4}{*}{ 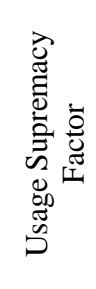 } & $\begin{array}{l}\text { I am using my phone } \\
\text { longer than intended }\end{array}$ & 0.724 & \multirow{4}{*}{ 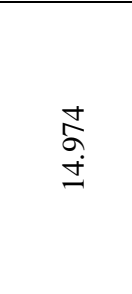 } & \multirow{4}{*}{ 芯 } \\
\hline & $\begin{array}{l}\text { I tried hard to control my } \\
\text { addiction towards phone }\end{array}$ & 0.678 & & \\
\hline & $\begin{array}{l}\text { I often regretted for } \\
\text { using phone for long } \\
\text { hours }\end{array}$ & 0.662 & & \\
\hline & $\begin{array}{l}\text { I am obsessed due to my } \\
\text { phone }\end{array}$ & 0.658 & & \\
\hline \multicolumn{5}{|c|}{$\begin{array}{c}\text { Total Variance }=52.292 \% ; \text { Cronbach's Alpha Value }=\mathbf{0 . 8 9 9} \text { of } 18 \\
\text { items }\end{array}$} \\
\hline \multicolumn{5}{|c|}{$\begin{array}{c}\text { KMO and Bartlett's Test } \\
\text { Kaiser-Meyer-Olkin Measure of Sampling Adequacy }=0.900 \\
\text { (Bartlett's Test of Sphericity Approx. Chi-Square : 1123.572; Df = } \\
\text { 153;P-Value }=<0.001)\end{array}$} \\
\hline
\end{tabular}

Tables 2 shows that KMO measure of Sampling Adequacy Value of 0.900 and Chi-Square value of 1123.572 at degrees of freedom of 153 with P-Value of $<0.001$ in Barlett's Test of Sphericity proves that factor analysis can be applied for all the eighteen internet and smart phone addiction variables. Three factors have been extracted out of eighteen variables and they explain $52.225 \%$ of the variance in the internet and smart phone addiction variables. Thus, all the internet and smart phone addiction variables have been reduced to Three independent factors and the most dominant factor is
Cognitive confinement Factor (CCF) followed by, Laxness Factor (LF) and Usage Supremacy Factor (USF) in their order of dominance.

\section{IMPLICATIONS AND CONCLUSION}

This empirical investigation proves that college students have higher internet and smart phone addiction in their day-day-lives. The result indicates that youth are having higher usage of smart phone and internet and they feel very restless when they don't use them regularly. The college student feels very nervous when they post any picture or information and they not get any likes and shares for the same. The exploration of internet and smart phone addiction are grouped into three dimensions such as, cognitive confinement, laxness and usage supremacy especially among college youth. The college youth are suggested to have self-control and determination to reduce the usage of internet and smart phone for unnecessary use. They should feel comfortable in the real world rather than the virtual world. The college students are shown more negligence to mental and physical problems and issues that caused by internet and smart phone addition. So, they should focus an activity that provides physical and mental health and happiness in their life. College students are suggested to use the resourceful and informative mobile applications for the enrichment of their knowledge rather than just passing the valuable time in internet and smart phone.

\section{REFERENCES}

1. Kim, D., Lee, Y., Lee, J., Nam, J. K., \& Chung, Y. (2014). Development of Korean smartphone addiction proneness scale for youth. PloS one, 9(5), e97920

2. Kwon, M., Kim, D. J., Cho, H., \& Yang, S. (2013). The smartphone addiction scale: development and validation of a short version for adolescents. PloS one, 8(12).

3. Kwon, M., Lee, J. Y., Won, W. Y., Park, J. W., Min, J. A., Hahn, C., ... \& Kim, D. J. (2013). Development and validation of a smartphone addiction scale (SAS). PloS one, 8(2), e56936.

4. Kwon, M., Lee, J. Y., Won, W. Y., Park, J. W., Min, J. A., Hahn, C., ... \& Kim, D. J. (2013). Development and validation of a smartphone addiction scale (SAS). PloS one, 8(2), e56936.

5. Rozgonjuk, D., Rosenvald, V., Janno, S., \&Täht, K. (2016). Developing a shorter version of the Estonian smartphone addiction proneness scale (E-SAPS18). Cyberpsychology: Journal of Psychosocial Research on Cyberspace, 10(4).

6. Russell, D , Peplau, L. A.. \& Ferguson, M. L. (1978). Developing a measure of loneliness.Journal of Personality Assessment, 42, 290-294.

7. Russell, D. (1996). UCLA Loneliness Scale (Version 3): Reliability, validity, and factor structure. Journal of Personality Assessment, 66, 20-40.

8. Alosaimi, F. D., Alyahya, H., Alshahwan, H., Al Mahyijari, N., \& Shaik, S. A. (2016). Smartphone addiction among university students in Riyadh, Saudi Arabia. Saudi medical journal, 37(6), 675

9. Haug, S., Castro, R. P., Kwon, M., Filler, A., Kowatsch, T., \& Schaub M. P. (2015). Smartphone use and smartphone addiction among young people in Switzerland. Journal of behavioral addictions, 4(4), 299-307.

10. Sharma, A., Sahu, R., Kasar, P. K., \& Sharma, R. (2014). Internet addiction among professional courses students: A study from central India. Int J Med Sci Public Health, 3(9), 1069-73.

11. Young, K. S. (2007). Cognitive behavior therapy with Internet addicts treatment outcomes and implications. CyberPsychology\& Behavior, 10(5), 671-679.

12. Kibona, L., \&Mgaya, G. (2015). Smartphones' effects on academic performance of higher learning students. Journal of Multidisciplinary Engineering Science and Technology, 2(4), 777-784.

13. Nayak, J. K. (2018). Relationship among smartphone usage, addiction, academic performance and the moderating role of gender: A study of higher education students in India. Computers \& Education, $123,164-173$. 


\section{AUTHORS PROFILE}

Ms. G. Archana, Ph.D. Research Scholar, Department of Commerce (General), VISTAS, Chennai. Her specialization for doctoral research is in the field of social media marketing and consumer behavior. She has received her Under-Graduation and Post-Graduation in Commerce from Stella maris college, Chennai.She has received Gold Medal for securing overall proficiency in post-graduation. She has cleared Tamil Nadu State- Level Eligibility Test in Commerce. Shewas contributed many empirical research articles to various eminent national and international level journals in the field of commerce and management indexed in SCOPUS/UGC CARE listed Journals and also actively participating in various national and international conferences.

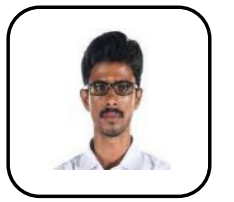

Dr. P. Balaji, Assistant Professor in Post Graduate and Research Department of Commerce, Guru Nanak College (Autonomous), Chennai. He has received Under-Graduation, Post-Graduation, Master of Philosophy and Doctor of Philosophy in Commerce from University of Madras, Chennai. He is the Life Member of Indian Commerce Association, Indian Accounting Association and Indian Finance Association. He possesses four years of research experience and one-year teaching experience in the realm of commerce. $\mathrm{He}$ has cleared UGC NET and Tamil Nadu SET in the subject of Commerce. He was specialized in teaching related to Banking, Marketing and Human Resource Management and has research interest in the field of Banking Technology, Marketing Research and Human Resource Development. He was received three best paper awards in various international and national conferences. He is the recipient of Doctoral Research Fellowship from Institute of Public Enterprise, Hyderabad in collaboration with Indian Council of Social Science Research (ICSSR) for the doctoral thesis awarded from Department of Commerce, School of Business and Management Studies, University of Madras, Chennai. 